\title{
Status of water security in inland South African cities
}

\author{
Thokozani Simelane \\ Human Sciences Research Council, South Africa \\ tsimelane@hsrc.ac.za \\ Claudious Chikozho \\ African Population and Health Research Centre, Kenya \\ Shingirirai Sevious Mutanga \\ Council for Scientific and Industrial Research, South Africa \\ Lavhelesani Rodney Managa \\ Human Sciences Research Council, South Africa \\ Fhulufelo Tshililo \\ Human Sciences Research Council, South Africa \\ Thandeka Dabata \\ Human Sciences Research Council, South Africa
}

\begin{abstract}
Most cities in South Africa are in dire need of water security. Intervention measures to reduce the risk of water shortages now and the near future are urgently needed. This can possibly be attained through the diversification of water sources and the application of smart or digital technologies to reduce water wastage. Meaning that, cities which are at risk of water scarcity may consider a variety of alternative means, which includes smart technologies and efficient use of recycled water to meet the ever-increasing demand. In this study the status of water security and sanitation in two inland cities (i.e. Mbombela (Nelspruit) and Polokwane (Pietersburg)) was investigated. A gap between supply and demand for water to households was found to be large. The primary demand for water derives from households that are connected to the municipal reticulation system and used for drinking and sanitation. Water security concerns were found to be from households in need of water supply and unmeasured demands from informal settlements that are illegally connected to the system. The uncertain nature of water availability due to climate change meant that the risk of water insecurity in studied cities was high. To ameliorate this, municipalities need to adopt new ways of managing water. This may include the use of digital technologies and the promotion of harvesting rainwater as an alternative source. Maintenance of existing infrastructure is highly recommended to improve efficiencies in water usage. Overall, results reflect the high risk of water security in Mbombela and Polokwane. Of great concern is the need to manage water to improve the efficiency of its use to meet the ever-increasing demand.
\end{abstract}

Keywords: Water demand, Water security, South Africa, Water supply 
Journal of Digital Food, Energy \& Water Systems, 1 (1): 34-64, 2020

ISSN 2709-4529

(c) Centre for Cyber Physical Food, Energy \& Water Systems

\section{Introduction}

From the city dynamics perspective, especially in South Africa, challenges linked to water and sanitation have escalated due to rapid urban migration, which took place since 1994 and the subsequent transformation of cities [1],[2]. Signs of water shortages in the cities have become imminent in many cities in South Africa. This have been experienced in coastal cities of Cape Town (Province of Western Cape), Port Elizabeth (Province of Western Cape) and Richardsbay (Province of KwaZulu Natal). Some cities and towns (e.g. Port Elizabeth, Beaufort West) are continuously experiencing unpredictable weather patterns that oscillates between droughts and floods. These have drastically affected water security in these cities and towns.

Water availability in any urban system is determined by a combination of enough precipitation (i.e. rainfall), well managed catchment area, healthy river system and the reliable infrastructure in the form of dams, reservoirs, pipes and taps. Quality of water consumed in each household relies on quality tests conducted by designated authorities.

Monitoring of consumption to improve water use efficiency has been increasingly performed through digital technologies. All these provide a basis for assured household water supply that is clean and drinkable. For South Africa, household water supply is dependent on total surface water available and the maintenance of infrastructure for bulk supply to consumers and households. The total surface water available for urban household consumption is estimated to be 49,200 million cubic meter $\left(\mathrm{m}^{3}\right)$ per year. In general, South Africa has relatively low per capita water availability compared to the global average, with only $9 \%$ of rainfall entering its river systems [3]. Thus, South Africa have low ratio of Mean Annual Precipitation to Mean Annual Run-off.

The question this brings forward, is whether emerging digital technologies can help the country enhance it water use, which have proved to be a scarce resource. South Africa's Department of Water Affairs and Forestry as a designated authority for water supply in the country has identified water security as a concern for major cities. It has acknowledged that cities anchor country's economy, and therefore, require investments to diversify water sources to ameliorate imminent water scarcity [4].

While this reality has emerged in the coastal city of Cape Town, developing trends point to the fact that almost all cities in South Africa are likely to face water shortages and this requires focused studies, adoption of new technologies (such as digital technologies) and collaboration among stakeholders to implement holistic water security and management strategies that will support both national and regional water security initiatives.

Given the context of South Africa, water scarcity and declining surface water quality, cities have no choice but to adopt smart water management that will allow them to efficiently use and manage available water resources. Smart water management in cities seeks to minimize challenges of urban water scarcities by integrating information and communication technologies to water management and administration [5],[6]. These technologies are adapted to continuously monitor water resources and diagnose problems, allowing to prioritize and to manage maintenance more effectively, as well as to gather data needed to optimize all aspects of water management in the city and feed 
Journal of Digital Food, Energy \& Water Systems, 1 (1): 34-64, 2020

ISSN 2709-4529

(c) Centre for Cyber Physical Food, Energy \& Water Systems

information back to planners, operators and technical service providers. These technologies entail water smart metering being implemented in number of municipalities [7],[8]. For South Africa the extent of deploying these technologies has not been ascertained. In this study it has been hypothesized that inland cities are more vulnerable to water scarcity as they do not have alternative sources of water such as saline water from the sea, which they can process through desalination technologies and use as an alternative to freshwater. Therefore, adoption of technologies such as digital technologies to augment the monitoring and efficient use of water resources is the viable option for these cities.

Access to water in South Africa as reported by the Department of Water and Sanitation highlights the institutional roles (i.e. provincial government, catchment management authorities, local government etc) in the management of water supply to households. This implies that in South Africa the provision of water and sanitation services lies squarely on the hands of local governments and municipalities. These are the ones that need to give digital technologies a serious consideration.

This study considered water challenges in South Africa as emanating from:

$>$ service delivery backlogs-people who have never enjoyed access to water supplies since 1994;

$>$ refurbishment backlogs-infrastructure that has deteriorated due to poor maintenance;

$>$ extension backlogs-existing infrastructure that needs to be extended to under services areas and new developments;

$>$ upgrade requirements-enhancement of infrastructure that does not meet the minimum standards;

$>$ operation and maintenance backlogs-infrastructure that has not been properly operated and maintained but can be brought to the mainstream if funds are allocated.

With the unpredictable nature of climate change and its impact on water security, assuring the provision of water under times of uncertainty present a complex scenario that requires new scientific approaches, which might include the use of digital technologies. The rationale for this study was therefore to unbundle the complex nature of water supply, its security and management in inland cities, which unlike coastal cities (that can harvest marine water through desalinating technologies) have limited options.

\section{Related work and contribution}

Across the World, competing interest for water has increased. This results from various uses of water. While in the past, water use and demand has largely been from household, agriculture, recreation and industrial operations, the intensification of the World to migrate to renewable energy and investments made on hydropower has brought the World's attention to the sustainability of available water.

Its continuous use for energy has become a bone of contention among scholars, policy makers and regulators. The additional threat from climate change on water security 
and its availability has help develop many perceptions about the value of water. As a result, increased research efforts has been given to predicting the future availability of water [9],[10], mapping the amount of water available for human use [11],[12], raising concerns about the nature and extent of water pollution [13], [14] and predicting effects of climate change on water and the associated systems like rivers and catchment areas [15]. In addition, some scientists have been developing technologies for either averting water crisis [16],[17]), proposed methods for reuse of contaminated water or looking at new sources of water [18],[19],[20]). Digital technologies are also being investigated as part of improving the efficient use of water resources.

The United Nations, through the Sustainable Development Goal number 6 expressed its desire to guide the World towards ensuring access to clean water, improve water quality and ensure its sustainable management, and further support and strengthen the participation of local communities in improving water management.

This together with the growing awareness for securing the availability of water for sustainable development has inspired researchers to generate more knowledge on water security, its management, availability and technologies that can be adopted to secure future availability of water.

As a contribution to the body of knowledge that is being developed, this article seeks to contribute to the body of knowledge that has so far generated. The location (two provinces in South Africa) of the study and its participants (communities from Polokwane and Mbombela cities) makes it unique and original. However, to ensure comparison to other studies conducted elsewhere, research methods applied, and the approaches used to analyze data are in line with the common acceptable scientific norms and procedures.

While concerns on water are increasing around the globe, this study focused on household water demand and supply. It sought to determine the status of water security in Mbombela and Polokwane and the vulnerability of these cities to water shortages, possibly due to climate change.

Data presented was collected (i.e. end of 2018) at the time when cities in South Africa were concerned about their state of water security as the city of Cape town was experiencing a possibility of running out of water.

\section{Study Method}

The study used structured household survey method for data collection, with special focus given to key informants as sources of information. The data was collected using questionnaires. Data from each questionnaire was captured into Cspro software saved into SAV file that was later loaded into SPSS software for analysis and interpretation.

The design of the study was as follows: 


\subsection{Sample size estimation}

The sample size was calculated at $95 \%$ level of confidence with the value of $Z$ being 1.96 and precision being at $5 \%$. Sample size estimation is a mathematical procedure used to determine the number of individuals to be included in the investigation from the population.

Determining the minimum required sample size is of extreme importance in achieving a scientifically and statistically acceptable results [21]. The formula developed by Naing, et al. [22] was used to calculate the required number of household to be targeted for each study area. The formula used is defined as:

$$
n=\frac{Z_{\alpha / 2}^{2} P(1-P)}{d^{2}}
$$

Where :

$n$ is the sample size

$\mathrm{Z}$ is the $\mathrm{Z}$ statistic for a level of confidence

$P$ is the prevalence or proportion of event of interest for the study

$\mathrm{d}$ is the precision/margin of error with which the researcher wants to measure something.

The sample size only provides an indication of the number of households to be targeted. It does not accout for non-response and incomplete surveys [23]. A proportion of participant were expected not to grant consent to participate in the survey. To account for this, the sample size was adjusted accordingly. Adjustments were made using the following formula:

$$
N^{\prime}=\frac{N}{1-q}
$$

Where $\mathrm{N}$ is the sample size

$\mathrm{q}$ is the proportion of the attrition and is generally $10 \%$

The study assumed a non-response rate of $10 \%$. As such the final adjusted sample size was 385 (Polokwane) and 360 (Mbombela). Forty-five households were added for Polokwane to adjust the final acceptable sample size to 430 households and, thirty-six were added to adjust the final sample size to 400 households.

\subsection{Household sampling}

Households included in the study were randomly selected using ArcGIS software. A shape file obtained from Statistic South Africa with households and streets was over laid on ArcGIS. Based on the sample size, Small local area layers (SALs) were generated using ArcGIS (Figure 4.3 and Figure 4.4). Visiting points were allocated unique number for ease of reference and recording. 


\subsection{Data Analysis}

Quantitative data analysis was performed on Statistical package for Social Sciences. Data analysis conducted was limited to descriptive analysis. This was supplemented with data interpretation using systems thinking and interpretation. This method was used to determine the linkages between various elements of water supply and demand processes through which water is provided to households of studied cities.

The application of system dynamics perspectives as a quantitative policy analysis technique has increased within the international water sector, with its use being frequently applied to investigate challenges of water supply and demand in urban systems.

By comparison, the application of systems science to urban water management in the developing world in general, and Africa is inadequate. Few applications of the application of this technique in South Africa include the determination of the relation between a municipality and the physical dynamics of an estuary [24], and as part of modelling the South African Green economy. Qualitative data from key informants was synthesized by examining the recurring responses.

\section{Description of the study area}

\subsection{Polokwane city}

Polokwane city is in the central part of the Limpopo Province, within the Capricorn District Municipality. It shares boarders with three local municipalities including Mopani and Waterberg. Polokwane city covers an extensive surface area of $3775 \mathrm{Km}^{2}$, accounting for $3 \%$ of the Limpopo Province total surface area. Within the Capricorn District, Polokwane city has the highest population.

The majority (71\%) of Polokwane is rural, with only $23 \%$ of the total area being urban. The remaining $6 \%$ of Polokwane is comprised of smallholdings, institutional, industrial and recreational land. Because of its central location the city of Polokwane being is located at the nexus of important national and provincial roads which radiates like the spokes of the wheels thus connecting countries such as Zimbabwe to other provinces like Gauteng in South Africa

\subsubsection{Demographic}

Polokwane is a home to 702190 people which is $11.63 \%$ more than in 2011 (628 999) (Table 1). Currently there are 214646 households $17 \%$ more than in 2011 (178 001). The number of households are increasing at a faster rate that the population. The average size of households is four persons per household. From 2007, the population growth rate was $2.8 \%$. Seshego (a large township in the city) has the highest population density (i.e. $27.2 \mathrm{person} / \mathrm{ha}$ ) followed by the city cluster with 8.5 person/ha (Table 1). 
Journal of Digital Food, Energy \& Water Systems, 1 (1): 34-64, 2020

ISSN 2709-4529

(c) Centre for Cyber Physical Food, Energy \& Water Systems

Table 1: Population in Polokwane municipality from 1996 to 2016 (Stats SA)

\begin{tabular}{lcccc}
\cline { 2 - 5 } & $\mathbf{1 9 9 6}$ & $\mathbf{2 0 0 1}$ & $\mathbf{2 0 1 1}$ & $\mathbf{2 0 1 6}$ \\
\cline { 2 - 5 } Total number of people & 424835 & 508277 & 628999 & 702190 \\
Total number of households & 85373 & 124975 & 178001 & 214464
\end{tabular}

\subsubsection{Climate}

Polokwane Local municipality is characterized by a semi-arid climate. Frost rarely occurs. It has a dry climate with summer rainfall and pronounced dry spells in winter. Rainy season last from October to March with peak rainfall in December/January. Rainfall occurs in a form of thunderstorms. The mean annual rainfall is $478 \mathrm{~mm}$. The mean maximum and minimum air temperatures are $22^{\circ} \mathrm{C}$ and $4.4^{\circ} \mathrm{C}$ respectively. These occur in January and July. Dry season lasts from May to October.

\subsubsection{Water resources}

Most of the river within the municipality are non-perennial rivers [25] as they are often dry in winter. Rivers within the Polokwane city include Blood, Sand, Brak, Diep, Nkumpi, Chuene and Mphogadiba River [26]. There are also no major dams within the municipality [27]. Until 1958, Polokwane municipality solely depended on groundwater. When demand for water could not be met by groundwater sources, water had to be imported from the neighboring drainage regions. Dap Naude dam located in the upper reaches of the Great Letaba River started supplying water to the municipality in 1958, followed by Ebenezer in 1974. About $60 \%$ of the Polokwane Local Municipality water is sourced outside the municipal boundaries therefore is water scarce. Surface water is transferred from outside the municipal boundaries through Ebenezer, Dup Naude and Olifants Sand water transfer mains. Polokwane city supplements surface water with ground water. In rural or distant areas, groundwater is the only source of water. However, in these areas there is low potential for ground water. Underdeveloped high potential ground water sources occur in Polokwane/Seshego, Sebageng, and Molepo. However, they are not fully utilized because of regional water schemes. The municipality has five medium size dams namely: Seshego, Houtriver, and Molepo, Mashashane, and Chuene/Maja dam. Provision of water in the municipality is divided into Regional Water Schemes. At Polokwane city, there are currently 14 regional water schemes namely: Mothapo, Moletjie East, Moletji North, Moletji South, Houtriver, Chuene/Maja, Molepo, Laastehoop, Mankweng, Boyne, Segwasi, Badimong, Sebayeng/Dikgale and Olifant Sand. The daily average demand for the municipality is $80.83 \mathrm{MI} /$ Day with peak demand of $163 \mathrm{MI} /$ Day. The municipality receives $80-90$ $\mathrm{MI} /$ Day and it is therefore not able to meet its peak flow demand of $163 \mathrm{MI} / \mathrm{Day}$. Because of water supply limitation, on 15 April 2013 a moratorium on new property development was issued for Polokwane city but has since been lifted. When it comes to water, the municipality experiences following challenges: 
$>$ Lack of sustainable water sources for current and future demand

$>$ Overreliance on borehole water in rural areas where there is a risk of water contamination by pit latrines

$>$ Aging and deterioration of water infrastructure, which leads to frequent pipe, burst in Polokwane city, Seshego, Annandale.

$>$ Lack of maintenance plan

$>$ Limited operation and maintenance of infrastructure due to lack /shortage of funds

$>$ Significant water loses within the distribution water networks

$>$ Illegal house expansion (Backyard rooms)

$>$ Pollution threat to underground water in the sand river catchment form the Polokwane cemetery and Seshego Sewerage works

$>$ High levels of water loss $(48 \%)$

Table 2: Regional water schemes sources and capacity [28]

\begin{tabular}{|c|c|c|c|}
\hline Water sources & RWS supplies & $\begin{array}{l}\text { Average } \\
\text { supply }\end{array}$ & $\begin{array}{l}\text { Source ca- } \\
\text { pacity }\end{array}$ \\
\hline Ebenezer & Mankweng RWS & $10 \mathrm{MI} /$ Day & \multirow[t]{2}{*}{$19 \mathrm{MI} / \mathrm{Day}$} \\
\hline Olifants Sand & $\begin{array}{l}\text { Rural (Mothapo RWS,Molepo } \\
\text { RWS,Segwasi RWS,Bonye } \\
\text { RWS,Badimong RWS,Sebayeng } \\
\text { Dikgale RWS) }\end{array}$ & $9 \mathrm{Ml} / \mathrm{Day}$ & \\
\hline Olifants Sand & $\begin{array}{l}\text { Chuene/Maja RWS,Olifants } \\
\text { Sand RWS (Seshego, some por- } \\
\text { tion of City and Mmotong wa } \\
\text { Perikisi) }\end{array}$ & $\begin{array}{l}26.29 \\
\text { MI/Day }\end{array}$ & 27 MI/Day \\
\hline $\begin{array}{l}\text { Dap Naude } \\
\text { Dam }\end{array}$ & $\begin{array}{l}\text { Olifants Sand RWS (Polokwane } \\
\text { City) }\end{array}$ & 15 MI/Day & $18 \mathrm{MI} / \mathrm{Day}$ \\
\hline Seshego Dam & $\begin{array}{l}\text { Olifants Sand RWS(Seshego } \\
\text { RWS) }\end{array}$ & $1.6 \mathrm{MI} /$ Day & $3.9 \mathrm{MI} /$ Day \\
\hline $\begin{array}{l}\text { Seshego Bore- } \\
\text { hole }\end{array}$ & Olifant Sand RWS (Seshego) & $1.2 \mathrm{MI} / \mathrm{Day}$ & $2.0 \mathrm{MI} / \mathrm{Day}$ \\
\hline Ebenezer & City & 19 MI/Day & $19 \mathrm{MI} / \mathrm{Day}$ \\
\hline Boreholes & Supplement water from dams & $5.5 \mathrm{MI} / \mathrm{Day}$ & $25.33 \mathrm{MI} / \mathrm{Day}$ \\
\hline Rural Dams & & & \\
\hline Houtriver Dam & Houtriver RWS & $2.0 \mathrm{MI} / \mathrm{Day}$ & 3.9 MI/Day \\
\hline $\begin{array}{l}\text { Chuene/Maja } \\
\text { Dam }\end{array}$ & Chuene/Maja RWS & 2.7 MI/Day & $2.7 \mathrm{MI} / \mathrm{Day}$ \\
\hline Molepo Dam & Molepo RWS & 6.0 MI/Day & $6 \mathrm{MI} / \mathrm{Day}$ \\
\hline
\end{tabular}


Journal of Digital Food, Energy \& Water Systems, 1 (1): 34-64, 2020 ISSN 2709-4529

(c) Centre for Cyber Physical Food, Energy \& Water Systems

\begin{tabular}{|l|l|l|l|}
\hline $\begin{array}{l}\text { Mashashane } \\
\text { Dam }\end{array}$ & Aganang RWS & 1.0 MI/Day & \\
\hline Total & & 99.29 & 124.83 \\
& MI/Day & MI/Day \\
\hline $\begin{array}{l}\text { Peak flow de- } \\
\text { mand }\end{array}$ & & 163 MI/Day & \\
\hline
\end{tabular}

\subsubsection{Acess to water and sanitation}

Currently, $83 \%$ (196 371) of the households in city of Polokwane has access to safe drinking water. The municipality has $17 \%(42745)$ households with no access to piped water (Table 3). The elimination of the water backlog is challenged by limited and /or unsustainable source of water found in rural areas and continuous increase of new settlements in some clusters in the municipal areas.

According to 2016 community survey, $36 \%$ (86 132) of households in Polokwane Local Municipality do not have access to healthy and dignified health facilities (Table 4). Even though over the years the municipality has made progress in provision of the sanitation services the municipality did not meet the Millennium Development Goals. The municipality needs R500 000 000t o eradicate the current sanitation backlog [29].

\subsection{Mbombela city}

The City of Mbombela (Nelspruit) is in the Ehlanzeni District Municipality, Mpumalanga Province. The municipality was formed in 2000 by the merger of Hazyview, Nelspruit and White River Local Councils. It is situated in the north eastern part of South Africa within the Lowveld sub-region of the Mpumalanga Province. It is bordered by six other Municipalities i.e. Bushbuck Ridge to the north, Nkomazi, Umjindi and Albert Luthuli to the south east and south and Highlands and Thaba Chweu to the south west and north-west.

The urban and peri-urban nodes of the municipality include Matsulu, kaNyamazane, Daantjie and Kabokweni. The rural nodes are Hazyview-Mganduzweni planning area, the Nsikazi planning area, Luphisi/Mpakeni villages and Elandshoek in the Ngodwana planning area [30].

\subsubsection{Demographic}

The population of Mbombela has had a 1.25\% growth since 2011 till 2016, with the total population increasing from 588,794 to 695,914 [31]. The growth rate however form the 2016 Community Survey has been projected to $2.11 \%$. The working population of Mbombela has varied from $66.2 \%$ in 2011 to $63.9 \%$ in 2016. The youth unemployment rate stood at $28.1 \%$ of the economically active. The increasing population 
Journal of Digital Food, Energy \& Water Systems, 1 (1): 34-64, 2020

ISSN 2709-4529

(C) Centre for Cyber Physical Food, Energy \& Water Systems

and the ever-increasing unemployment rate in South Africa have led to several households not being able to make ends meet, thus the increase in the dependency ratio on the government resources and services from $51.6 \%$ in 2011 to $56.6 \%$ in 2016 .

Table 3: Population distribution according to race in Mbombela local municipality

\begin{tabular}{lcc}
\cline { 2 - 3 } Race/Population Group & \multicolumn{2}{c}{$\mathbf{2 0 1 6}$} \\
\cline { 2 - 3 } & Number of People & Percentage (\%) \\
\cline { 2 - 3 } Blacks (African) & 667827 & $95.96 \%$ \\
Whites & 18695 & $2.69 \%$ \\
Coloureds & 6535 & $0.94 \%$ \\
Asian & 2855 & $0.41 \%$ \\
\hline
\end{tabular}

Source: Stats SA, Community Survey 2016

\subsubsection{Climate}

Mbombela features a humid subtropical climate with mild winters and hot summers. Due to the altitude, summers are not as hot as one might expect. Summers are hot and somewhat humid, complete with high precipitation. Winters in the city are dry, with relatively warm temperatures during the day and chilly temperatures at night.

Like in many other parts of the country, the rainfall is unevenly distributed in the Inkomati Water Catchment Area where most of the rainfall occurs in the mountainous regions. Future predictions of hotter wetter summers and long drier winters as a result of climate change could greatly impact or affect water availability for in the area.

\subsubsection{Water resources}

Water availability is mainly driven by rainfall patterns that are strongly seasonal, and highly variable between places and between years. The Mean Annual Precipitation (MAP) varies from about $500 \mathrm{~mm}$ in the lowveld, to $1,500 \mathrm{~mm}$ on the escarpment at Kaapsehoop. The MAP in Nelspruit is $783 \mathrm{~mm}$, whereas White River has a MAP of $936 \mathrm{~mm}$ [32]. Some years receive up to 1.8 times the MAP, while other years receive as little as 0.55 times the MAP.

Mbombela local municipality (MLM) water needs are met through the Inkomati Water Management Area (WMA) and straddles the Crocodile (East) and Sabie River catchments. Much of the water flowing through the municipal area is derived from upstream catchments. The municipality obtains all their water from these catchments with a very small percentage obtained from groundwater.

Most of Mbombela is situated within the Crocodile River Catchment, and a small portion in the vicinity of Hazyview is situated in the Sabie River Catchment. Major tributaries within Mbombela include the lower Elands, Ngodwana, Nels, White, White 
Waters, Gutshwa, North Sand and Nzikazi Rivers. The river corridors provide important migration routes for various plants and animals, playing an important role in linking lowveld areas with the escarpment and highveld.

There are six major water storage reservoirs within Mbombela, but the most important storage facility for the area, Kwena Dam, is situated outside the municipal boundary (Table 6). Much of the water on which Mbombela depends is therefore generated outside of the municipal boundary.

Table 4: Significant dams in the Crocodile River catchment

\begin{tabular}{|c|c|c|c|c|c|c|}
\hline Dam & \multirow{2}{*}{\multicolumn{2}{|c|}{$\begin{array}{l}\text { Fully supply ca- } \\
\text { pacity (FSC) } \\
\begin{array}{l}\text { Natural MAR (mil- } \\
\text { lion } \mathrm{m} 3 / \mathrm{a})\end{array}\end{array}$}} & \multicolumn{2}{|c|}{$\begin{array}{c}\text { Full supply area } \\
\text { (FSA) } \\
(\text { km2) }\end{array}$} & \multirow{2}{*}{\multicolumn{2}{|c|}{$\begin{array}{l}\begin{array}{l}\text { Yield } \\
\mathrm{m} 3 / \mathrm{a})\end{array} \\
1 \text { in } 50\end{array}$}} \\
\hline million $m 3$ & & & $\begin{array}{l}F S C \text { as } \\
\% M A R\end{array}$ & Historic & & \\
\hline Kwena Dam & 158,9 & 119 & $134 \%$ & 12,5 & 83,2 & 87,5 \\
\hline Witklip Dam & 12,7 & 19,8 & $64 \%$ & 1,88 & 8,1 & 8,5 \\
\hline Klipkopje Dam & 11,9 & 188 & $63 \%$ & 2,31 & $\begin{array}{r}\text { Opera } \\
\text { tem } \\
\text { Lon }\end{array}$ & $\begin{array}{l}\text { as sys- } \\
\text { h } \\
\text { re }\end{array}$ \\
\hline Longmere Dam & 4,32 & 25,4 & $17 \%$ & 0,96 & 10,3 & 10,6 \\
\hline Primkop Dam & 1,97 & 39,4 & $5 \%$ & 0,41 & 9,9 & 10,3 \\
\hline $\begin{array}{l}\text { Ngodwana } \\
\text { Dam }\end{array}$ & 10,0 & 58,8 & $17 \%$ & 1,00 & 21,0 & 22,4 \\
\hline TOTAL & 199,8 & 450,4 & $44 \%$ & 19,06 & 132,5 & 139,3 \\
\hline
\end{tabular}

Source: DWS 201

The Inkomati River originates in South Africa, passes through Swaziland, back through South Africa and finally drains into the Indian Ocean in Mozambique. The basin covers roughly 31,230 square kilometres with irrigated agriculture utilising $57 \%$ of the average water requirements [33]. On other hand, the water resources of the Crocodile and Sabie River catchment have two components; the yield available from dams (including farm dam) and the yield available from run-of-river. The significant dams in the Crocodile and Sabie River catchment are listed in Table 7.

Table 5: Significant dams in the Sabie River catchment

\begin{tabular}{|c|l|l|l|l|}
\hline Dam & \multicolumn{2}{|c|}{ Fully supply capacity (FSC) } & $\begin{array}{l}\text { Full supply } \\
\text { area } \\
\text { (FSA) } \\
\text { (km2) }\end{array}$ & $\begin{array}{l}\text { Yield (million } \\
\text { m3/a) }\end{array}$ \\
\hline Million m3 & $\begin{array}{l}\text { Natural MAR } \\
\text { (million m3/a) }\end{array}$ & $\begin{array}{l}\text { FSC as } \\
\% \text { MAR }\end{array}$ & Historic & 1 in 50 \\
\hline
\end{tabular}


Journal of Digital Food, Energy \& Water Systems, 1 (1): 34-64, 2020

ISSN 2709-4529

(C) Centre for Cyber Physical Food, Energy \& Water Systems

\begin{tabular}{|l|c|c|c|c|c|r|}
\hline $\begin{array}{l}\text { Inyaka } \\
\text { Dam }\end{array}$ & 125,0 & 79,9 & $156 \%$ & 8,1 & 41,9 & 50,7 \\
\hline $\begin{array}{l}\text { Da Gama } \\
\text { Dam }\end{array}$ & 13,6 & 20,3 & $67 \%$ & 1,3 & 10,3 & 10,8 \\
\hline $\begin{array}{l}\text { Maritsane } \\
\text { Dam }\end{array}$ & 2,1 & 24,9 & $8 \%$ & 0,5 & 7,5 & 10,5 \\
\hline TOTAL & $\mathbf{1 4 0 , 7}$ & $\mathbf{1 2 5 , 1}$ & $\mathbf{1 1 3 \%}$ & $\mathbf{9 , 9}$ & $\mathbf{5 9 , 7}$ & $\mathbf{7 2 , 0}$ \\
\hline
\end{tabular}

Source: DWS 2014

\subsubsection{Acess to water and sanitation}

According to Stats SA community survey [34]), number of households with access to safe drinking water was reported higher $(80.4 \%)$ compared to those without access to safe drinking water (19.6\%). However, not all households had piped water inside the dwelling/house, and some households were still having access to water from flowing river (Table 8).

In terms of access to basic sanitation, city of Mbombela still faced with huge challenge to provide dignified sanitation facility to all households. Stats SA community survey [35] reported that 114163 households still using pit latrine toilet facility, and $67.2 \%$ of those are without ventilation pipe (Table 9 ).

\section{$5 \quad$ Results}

\subsection{Polokwane}

\subsubsection{Community perspectives}

\section{Household data}

Of total surveyed household in Polokwane, 83.7 \% were staying in a house constructed with bricks or concrete that was located on a separate stand (Table 10). The number of occupants per household ranged between 1 and 15 with mean number of $5.38(\mathrm{STD}=3.29)$ people.

Table 6: Type of dwelling that the household occupies

\begin{tabular}{|l|l|l|}
\hline \multicolumn{1}{|c|}{ Type of dwelling } & n & \% \\
\hline $\begin{array}{l}\text { Dwelling /house or brick/concrete block structure on a separate stand } \\
\text { or yard or on farm }\end{array}$ & 349 & $\begin{array}{l}83, \\
7\end{array}$ \\
\hline Dwelling/house/flat/room in backyard & 33 & 7,9 \\
\hline Shack (Plastic/semi-permanent material/corrugated iron/cardboard) & 35 & 8,4 \\
\hline Total & $\mathbf{4 1 7}$ & $\mathbf{1 0 0}$ \\
\hline
\end{tabular}




\section{Sources of water for the households}

The main source of water for the most households (61.5\%) was piped tap that was located either inside the house (15.2\%) or somewhere in the yard (12.6\%) (Figure 1). For households that did not have tap inside the house or in the yard a communal tap was located 200 meters away from the household (Table 11). Small proportions were ether obtaining water from the neighbour, tank or borehole (Figure 2).

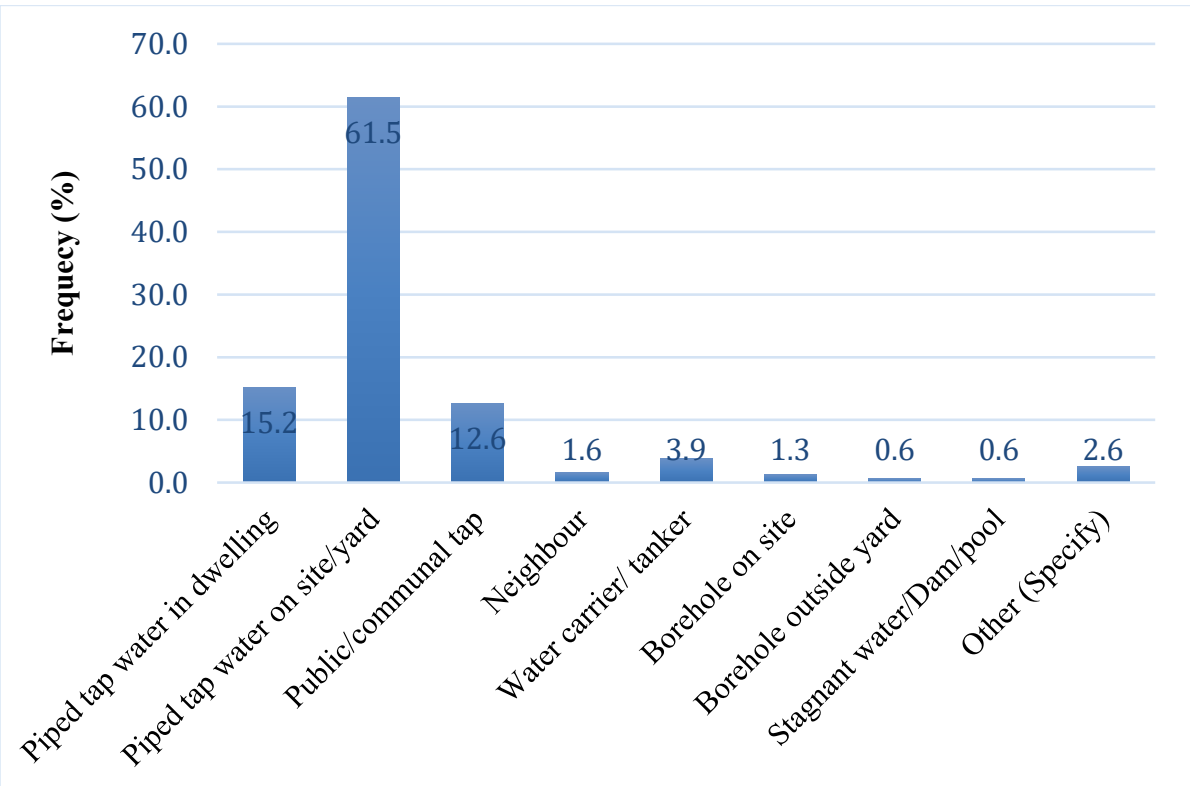

Figure 1: Sources of water for the household

Table 7: Distance of main source of water away from the dwelling

\begin{tabular}{|l|r|r|}
\hline \multicolumn{1}{|c|}{ Distance of main source of water from the household } & $\mathbf{n}$ & $\mathbf{\%}$ \\
\hline Water source is inside the house & 230 & 55,8 \\
\hline Water source is located less than 200 metres from the household & 147 & 35,7 \\
\hline $\begin{array}{l}\text { Water source is located between 201 - 500 metres from the } \\
\text { household }\end{array}$ & 19 & 4,6 \\
\hline $\begin{array}{l}\text { Water source is located between 501 metres - 1 kilometre from } \\
\text { the household }\end{array}$ & 8 & 1,9 \\
\hline $\begin{array}{l}\text { Water source is located more than 1 kilometre away from the } \\
\text { household }\end{array}$ & 5 & 1,2 \\
\hline
\end{tabular}


Journal of Digital Food, Energy \& Water Systems, 1 (1): 34-64, 2020

ISSN 2709-4529

(C) Centre for Cyber Physical Food, Energy \& Water Systems

\begin{tabular}{|l|r|r|}
\hline Don't Know & 3 & 0,7 \\
\hline Total & $\mathbf{4 1 2}$ & $\mathbf{1 0 0}$ \\
\hline
\end{tabular}

Access to safe drinking water

The majority of sampled household (92\%) were using tap water as their main source of drinking water while only $7 \%$ used the bottled water. The community perception towards safety of tap water was also observed, and $90 \%$ of the participants believed that the water was safe to drink, clear, good in taste and free from bad smell (Figure 2).

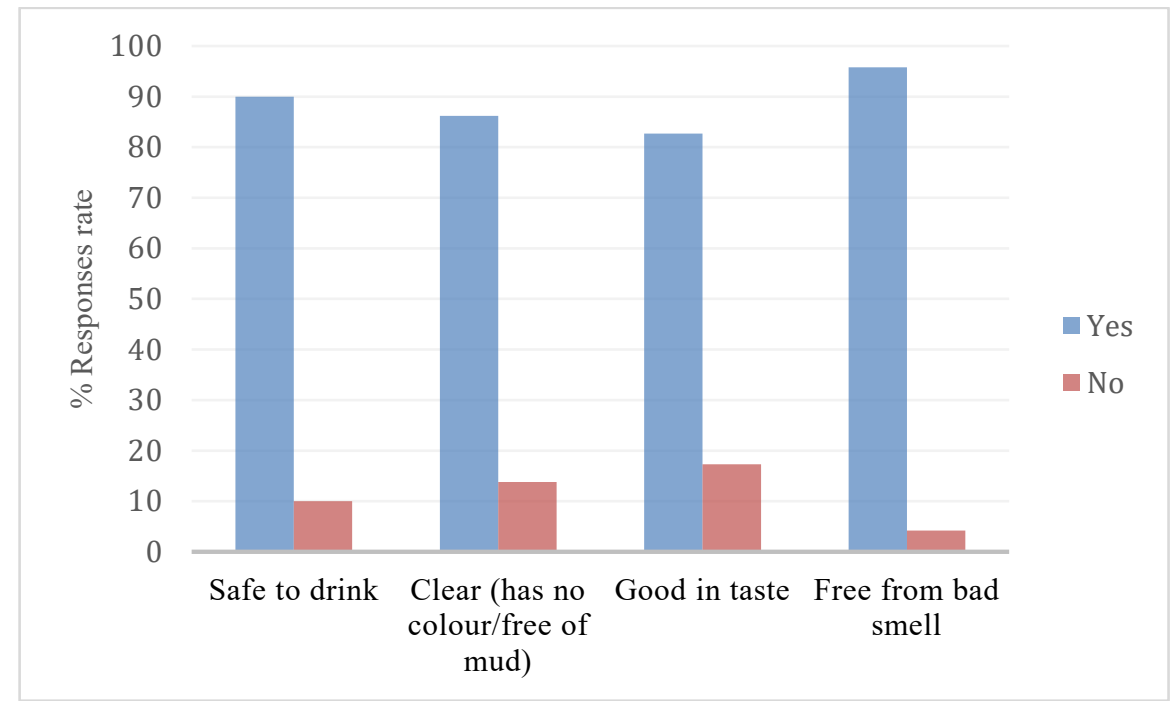

Figure 2: Proportion of study participants indicating whether water from the main source is safe or not

Water supply services

In the $87 \%$ of households, the main provider of drinking water was the municipality. However, only $41 \%$ of the household was paying for the municipal water service (Figure 6). There was various reason why household were not paying the municipal water services, which could be blamed on both the community and municipality (Table 13). 
(C) Centre for Cyber Physical Food, Energy \& Water Systems

Is your household paying for manicipal services

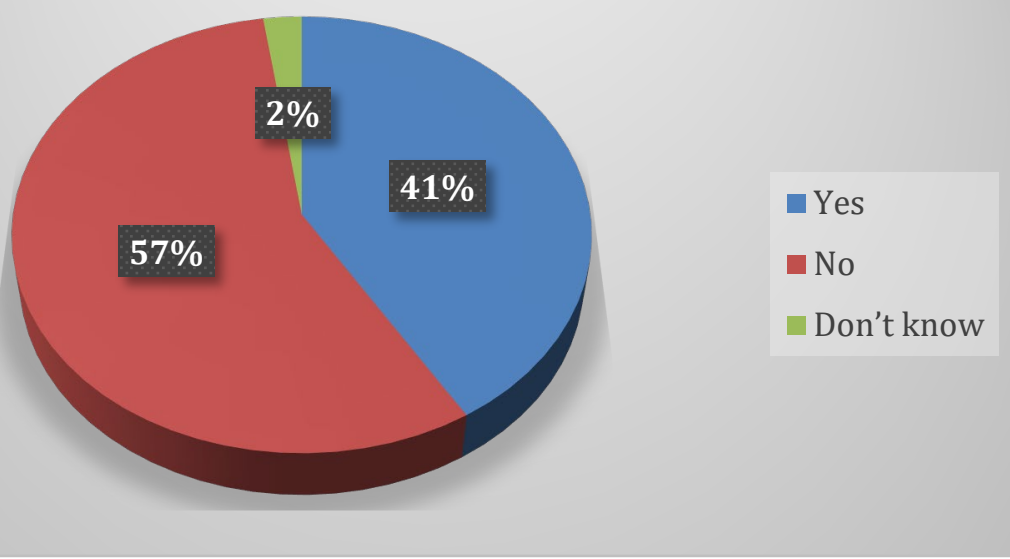

Figure 3: household paying for municipal water services

Table 8: Reason for not paying municipal water cited by the participants in the study area

\begin{tabular}{|l|c|c|}
\hline \multicolumn{1}{|c|}{ Reason provided } & $\mathbf{n}$ & $\mathbf{\%}$ \\
\hline Use own source of water & 12 & 6,1 \\
\hline Use a free water source & 31 & 15,7 \\
\hline Pay directly to landlord as part of rent & 32 & 16,2 \\
\hline Payment included in levy & 4 & 2,0 \\
\hline Permission from municipality not to pay & 29 & 14,7 \\
\hline Do not have water meter & 26 & 13,2 \\
\hline Water meter not working/broken & 14 & 7,1 \\
\hline Do not receive water bill & 10 & 5,1 \\
\hline Community decision not to pay & 6 & 3,0 \\
\hline Cannot afford to pay & 11 & 5,6 \\
\hline Water supply irregular & 10 & 5,1 \\
\hline Water supply has been stopped & 3 & 1,5 \\
\hline Other (specify) & 9 & 4,6 \\
\hline Total & $\mathbf{1 9 7}$ & $\mathbf{1 0 0}$ \\
\hline
\end{tabular}

Water supply interruption 
(C) Centre for Cyber Physical Food, Energy \& Water Systems

About $86 \%$ percent of the household had water interruption in the past 12 months before the survey (Figure 4). In most cases, the water interruption was longer than 2 days (Figure 5), and these could happen up to five (5) times in a month (Table 13). While the reason for water interruption could be due to scheduled maintenance, burst pipe or regular water cut routine, $47 \%$ household didn't know the reason why water had been interrupted (Table 14). However, the people had the alternative sources of water during the interruption, in which include the municipal water tank (Table 14).

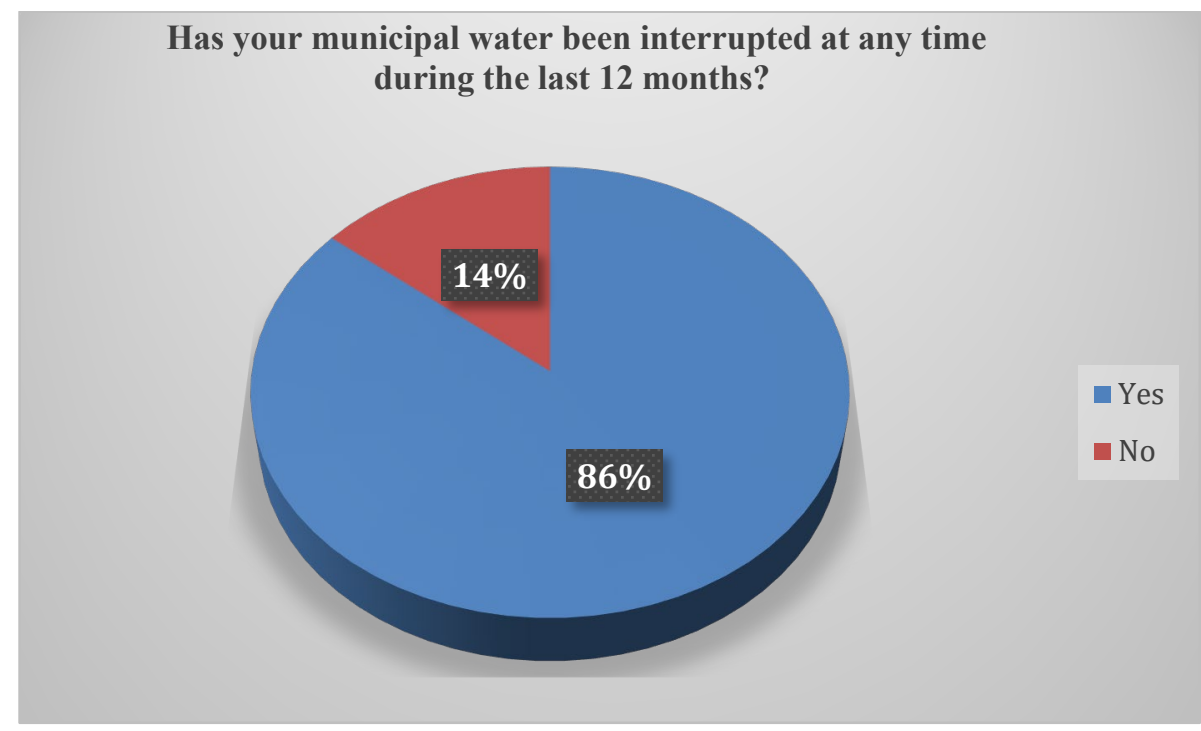

Figure 4: Water interruption in the past 12 month

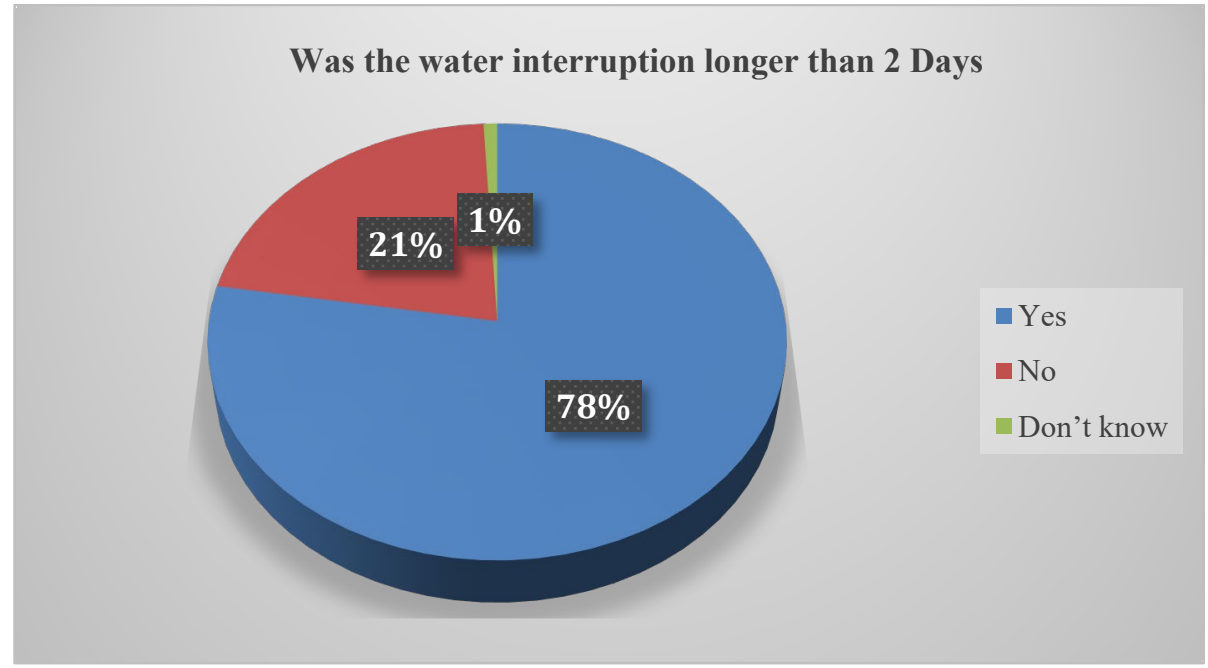

Figure 5: Duration of water interruption 
Journal of Digital Food, Energy \& Water Systems, 1 (1): 34-64, 2020

ISSN 2709-4529

(C) Centre for Cyber Physical Food, Energy \& Water Systems

Table 9: Household water interruptions situation in Polokwane

\begin{tabular}{|c|c|c|}
\hline \multirow{4}{*}{$\begin{array}{l}\text { How often do you get water inter- } \\
\text { ruptions in a month? }\end{array}$} & \multicolumn{2}{|c|}{ \% Responses } \\
\hline & 1-3 times & 61,7 \\
\hline & $4-5$ & 30,7 \\
\hline & Never & 7,7 \\
\hline \multicolumn{2}{|l|}{ Total } & 100 \\
\hline \multirow{3}{*}{$\begin{array}{l}\text { Alternative source of water during } \\
\text { the interruption }\end{array}$} & \multicolumn{2}{|c|}{ \% Responses } \\
\hline & $\begin{array}{l}\text { Bottled water/stored } \\
\text { water }\end{array}$ & 75,9 \\
\hline & $\begin{array}{l}\text { Municipal water tank- } \\
\text { ers }\end{array}$ & 24,1 \\
\hline \multicolumn{2}{|l|}{ Total } & 100 \\
\hline \multirow{6}{*}{ Main reason for water interruption } & \multicolumn{2}{|c|}{ \% Responses } \\
\hline & Scheduled maintenance & 17,1 \\
\hline & Burst pipe & 20,6 \\
\hline & Daily regular water cuts & 9,4 \\
\hline & Pressure & 5,6 \\
\hline & Do not know & 47,4 \\
\hline
\end{tabular}

Household water quality control measures

On their own capacity, the results show that only $2 \%$ of households always treat the water before drinking, while $8 \%$ do treat the water on occasional basis. Of those households who perform treatment on water, $56 \%$ used boiling as the standard water treatment method, while others used chemical and natural filtering methods (Figure 9). 
(C) Centre for Cyber Physical Food, Energy \& Water Systems

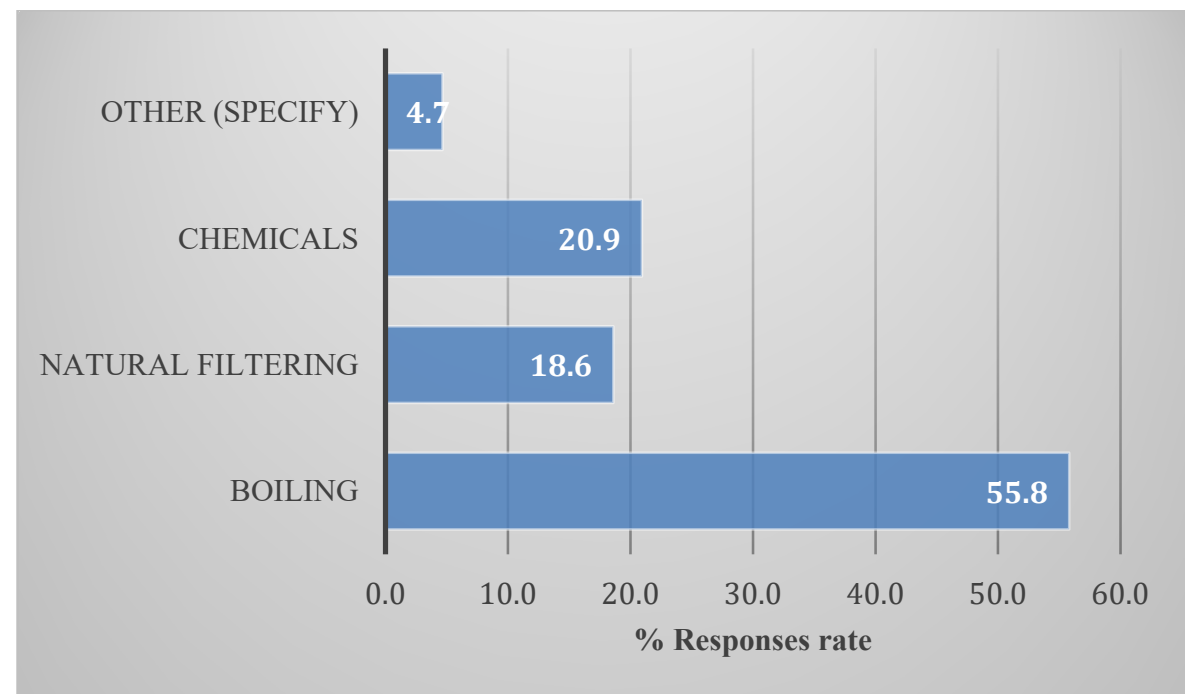

Figure 6: Methods used to treat water before drinking cited by the study participants

\section{Sanitation services}

As indicated in figure 7, over half (53.9\%) of visited households had flush toilet which is connected to the municipal sewage. Flush toilet connected to a septic tank also recorded in the area, but only accounted for $2.9 \%$. Pit latrine either ventilation pipe or without ventilation pipe accounted for $40.8 \%$ of total household. The use of chemical toilet as well as using nearby veld was not prevalent in the area. The general prevalence of wastewater or sewage spillage was not considered high in the area. However, $52 \%$ of the households felt that the rate at which municipality respond to emergence breakage or spillage is low. 


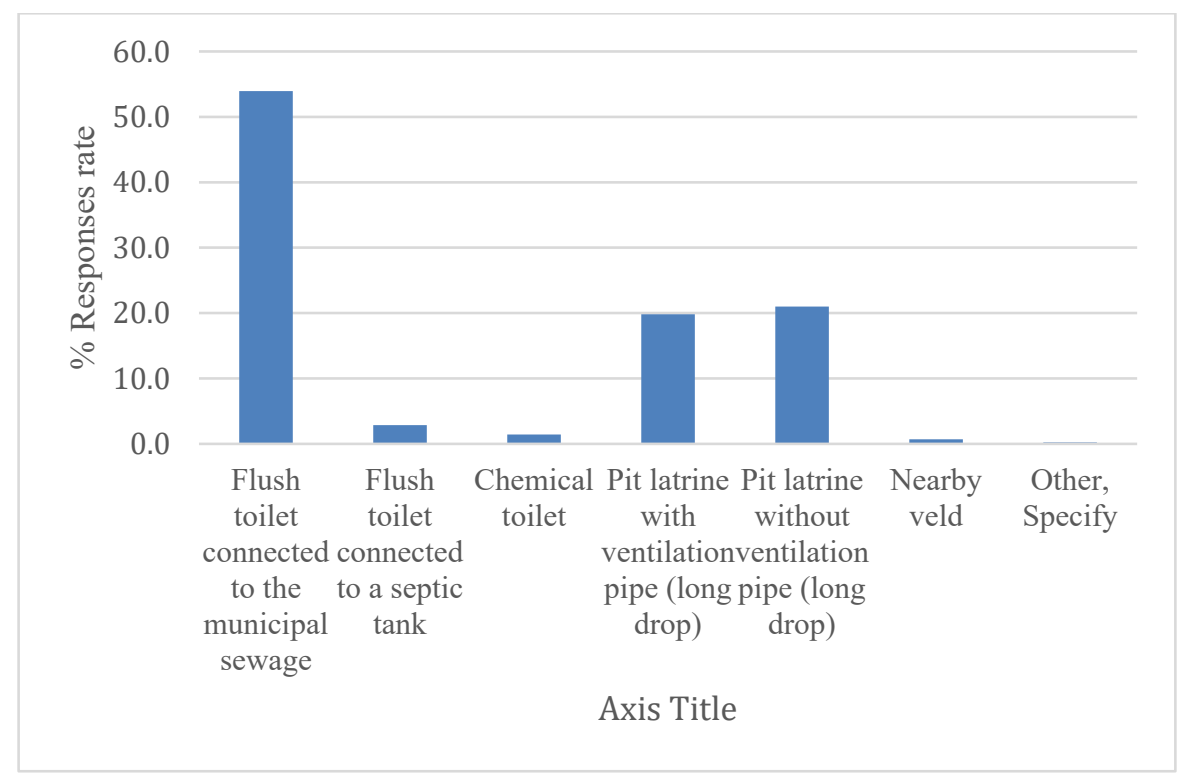

Figure 7: Type of toilet facility used by study participants in Polokwane city

\section{Perspective from stakeholders}

Stakeholders and service providers interviewed during the survey included officials from the Polokwane Local Municipality, Provincial Department of agriculture, and the Provincial office of the National Department of Water and Sanitation. Other role players in water and sanitation provision were LIMA rural development foundation, Oxfam Australia, Mvula trust and Private Service providers. According to the Polokwane local municipality, the status of water and sanitation is such that:-

a) The municipality is currently receiving between 80 to $99 \mathrm{Ml} / \mathrm{d}$ of water and is unable to meet the peak flow demand of $163 \mathrm{Ml} /$ day.

b) The Infrastructure is lacking behind the population growth and emerging settlements.

c) Pit latrines still exist, although there are efforts to provide flush toilets and improved structures of pit latrines (i.e. those with ventilation pipe).

d) There are still communities that do not have access to clean water especially in rural areas

The views expressed by the local municipality were also shared by the department of water and sanitation, which indicted that Polokwane city lacks sustainable water sources, and more than $60 \%$ of its water is sourced outside the boundaries of the Municipality. The primary concern raised was the amount of water lost during distribution due to aging infrastructure and lack of timely maintenance of burst pipes. 
To address this challenge, the municipality council in partnership with department of water and sanitation intends to invest more than R420 million to replace asbestos pipes in the Central Business District and the surrounding settlements.

To ensure the sustainability of limited water available to the municipality, the provincial department of agriculture indicated that it was encouraging farming households to employ water conservation farming practices and enhancing the capacity of households' harvest rainwater.

Regarding the monitoring of water quality, officials indicated that the water quality tests were conducted regularly. Water and sanitation experts from the University of Limpopo were concerned that there is a risk of ground water being contaminated in some areas due to backlog sanitation service that was not according to approved standards.

\subsection{Mbombela City}

\subsubsection{Community perspectives}

\section{Household data}

Of total surveyed households in Mbombela, $92 \%$ were staying in a household that was constructed with bricks or concrete that was located on a separate stand (Table 10). The number of occupants per household were varied among households with mean number of 4.59 people.

Table 10: Type of dwelling that the household occupies

\begin{tabular}{|l|c|c|}
\hline Household dwelling type & $\mathbf{n}$ & $\mathbf{\%}$ \\
\hline $\begin{array}{l}\text { Dwelling /house or brick/concrete block structure on a separate } \\
\text { stand or yard or on farm }\end{array}$ & 350 & 92,8 \\
\hline $\begin{array}{l}\text { Traditional dwelling /hut/structure made of traditional materials } \\
\text { (wattle \& Daub1/Mud) }\end{array}$ & 8 & 2,1 \\
\hline Double story dwelling & 5 & 1,3 \\
\hline Dwelling/house/flat/room in backyard & 4 & 1,1 \\
\hline $\begin{array}{l}\text { Shack (Plastic /semi-permanent material/corrugated iron/card- } \\
\text { board) }\end{array}$ & 9 & 2,4 \\
\hline Shipping container & 1 & 0,3 \\
\hline Total & $\mathbf{3 7 7}$ & $\mathbf{1 0 0}$ \\
\hline
\end{tabular}

Sources of water for the households

Majority of households (80\%) surveyed, the main source of water was the tap located either inside the house or somewhere in the yard (Figure 13). For households that did 
Journal of Digital Food, Energy \& Water Systems, 1 (1): 34-64, 2020

ISSN 2709-4529

(C) Centre for Cyber Physical Food, Energy \& Water Systems

not have water taps inside the house or in the yard, a communal tap was located 200 meters away from the household (Table 11).

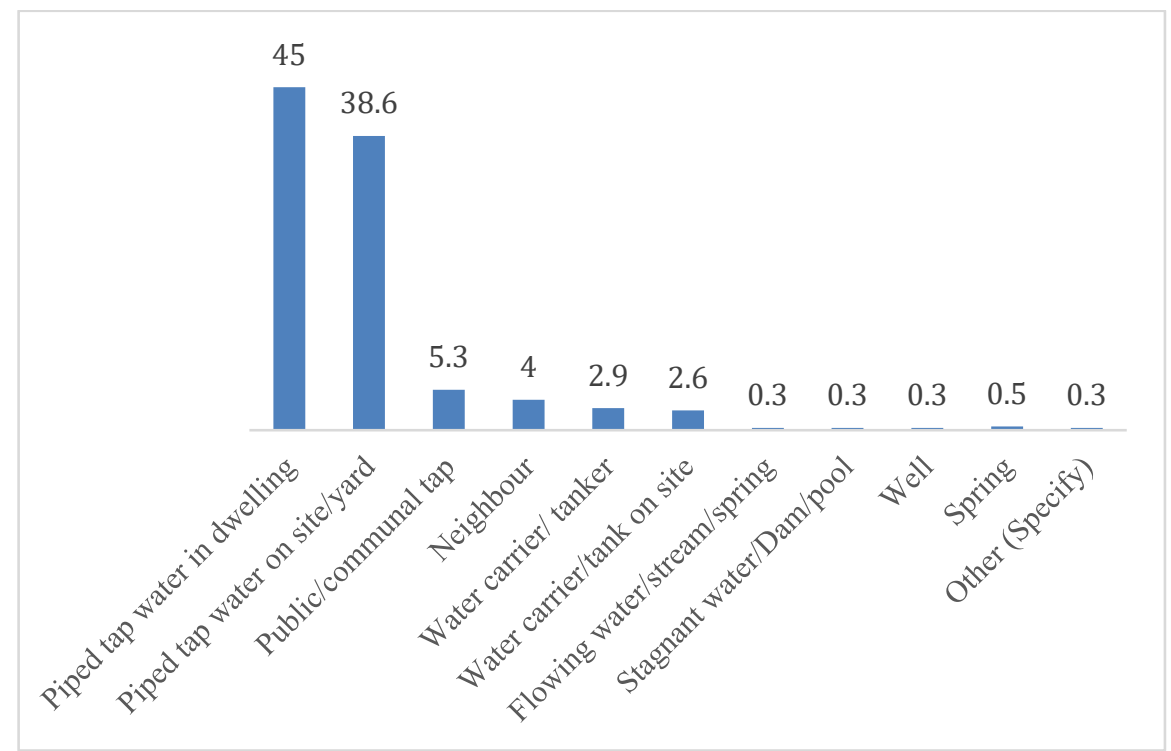

Figure 8: Main source of water for the surveyed household in the study area

Table 11: Distance of main source of water from the household dwelling

\begin{tabular}{|l|c|c|}
\hline Distance of main source of water from the household & $\mathbf{n}$ & $\mathbf{\%}$ \\
\hline Water source is inside the house & 127 & 34 \\
\hline Water source is less than 200 metres from the house & 216 & 57.9 \\
\hline Water source is between 201 - 500 metres from the house & 30 & 8.0 \\
\hline Total & $\mathbf{3 7 3}$ & $\mathbf{1 0 0}$ \\
\hline
\end{tabular}

Access to safe drinking water

$61 \%$ of households were obtaining water from the tap and $38 \%$ indicated that they were using bottled water. Most participants $(91.5 \%)$ believed the water from the sources was safe to drink (Table 12).

Table 12: Household perception on water safety

\begin{tabular}{|l|c|c|}
\hline Characteristics & Yes & No \\
\cline { 2 - 3 } & \multicolumn{2}{|c|}{ Percentage (\%) } \\
\hline
\end{tabular}


Journal of Digital Food, Energy \& Water Systems, 1 (1): 34-64, 2020

ISSN 2709-4529

(C) Centre for Cyber Physical Food, Energy \& Water Systems

\begin{tabular}{|l|l|l|}
\hline Safe to drink & 91.5 & 8.5 \\
\hline Clear (has no colour /free of mud) & 82 & 18 \\
\hline Good in taste & 87.6 & 12.4 \\
\hline Free from bad smell & 89.9 & 10.1 \\
\hline
\end{tabular}

Water supply services

Of total participants, $93 \%$ indicated that the municipality was the main provider of drinking water. But only $29 \%$ of households indicated that they regularly pay for water services. There were various reasons provided for not paying for water services (Table 13).

Table 13: Reason for not paying municipal water

\begin{tabular}{|l|c|c|}
\hline \multicolumn{1}{|c|}{ Reasons } & n & \% \\
\hline Use own source of water & 22 & 8,7 \\
\hline Use a free water source & 42 & 16,5 \\
\hline Pay directly to landlord as part of rent & 8 & 3,1 \\
\hline Payment included in levy & 2 & 0,8 \\
\hline Permission from municipality not to pay & 47 & 18,5 \\
\hline Do not have water meter & 46 & 18,1 \\
\hline Water meter not working/broken & 20 & 3,9 \\
\hline Do not receive water bill & 10 & 3,9 \\
\hline Community decision not to pay & 10 & 16,1 \\
\hline Cannot afford to pay & 41 & 1,6 \\
\hline Water supply irregular & 4 & 0,8 \\
\hline Other (specify) & 2 & $\mathbf{1 0 0}$ \\
\hline Total & $\mathbf{2 5 4}$ & \\
\hline
\end{tabular}

Water supply interruption

In terms of water interruptions, $96 \%$ of the households indicated that they had experienced water interruption in the past 12 months. In most cases, the water interruptions were longer than 2 days (Figure 9), and that was happening for up to five times in a month (Table 14). While at times water interruptions were a result of scheduled maintenance, burst pipe and regular water cut routine were some of the reasons why water supply was interrupted. As an alternative, various sources of water supply were used during the interruption, including the municipal water tank. 


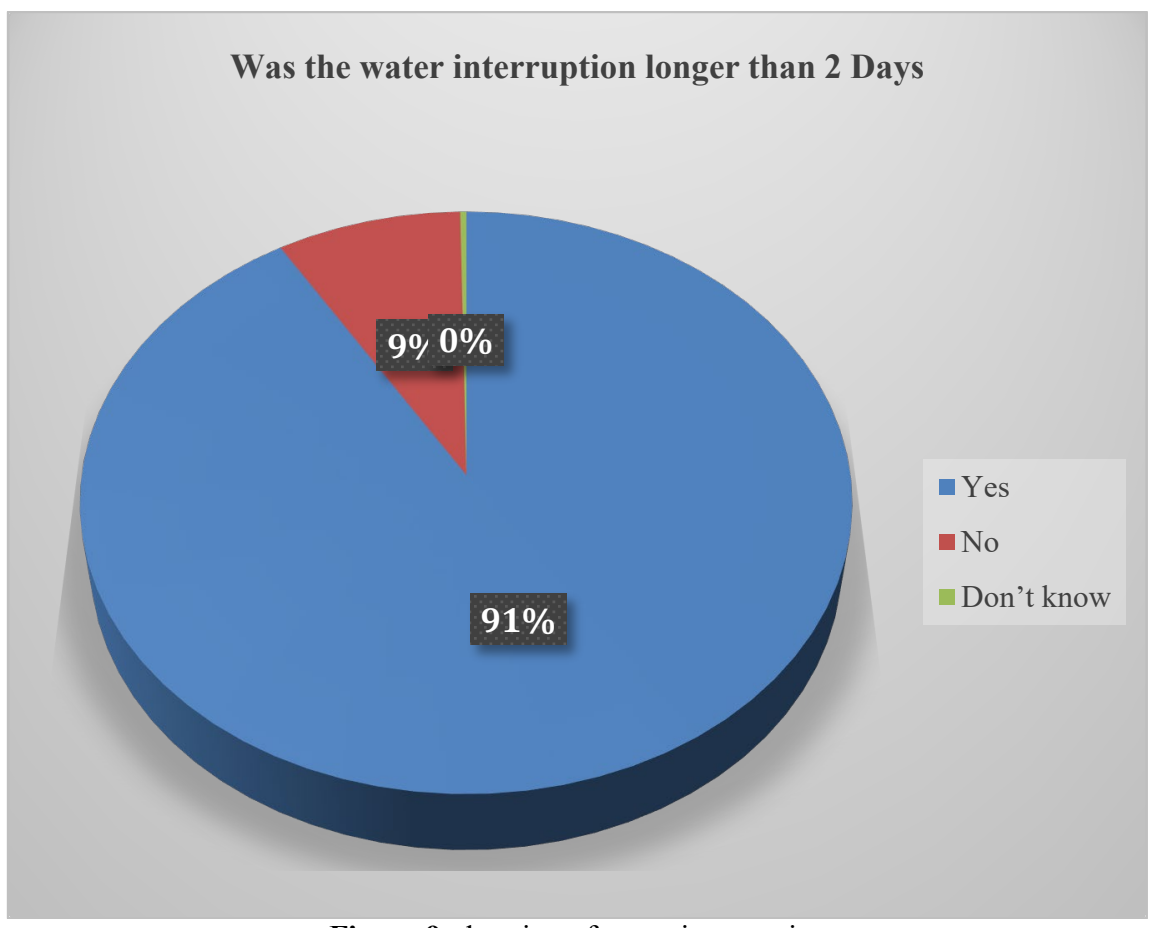

Figure 9: duration of water interruption

Table 14: Household water interruptions situation in Mbombela

\begin{tabular}{|c|l|r|}
\hline \multirow{2}{*}{$\begin{array}{l}\text { How often do you get water inter- } \\
\text { ruptions in a month? }\end{array}$} & \multicolumn{2}{|c|}{ \% Responses } \\
\cline { 2 - 3 } & $1-3$ times & 58,4 \\
\cline { 2 - 3 } & $4-5$ & 41,6 \\
\hline \multicolumn{2}{|c|}{ Total } & \multicolumn{1}{|c|}{ \% Responses } \\
\cline { 2 - 3 } & $\begin{array}{l}\text { Bottled water/stored } \\
\text { water }\end{array}$ & 69,2 \\
\cline { 2 - 3 } $\begin{array}{l}\text { Alternative source of water during } \\
\text { the interruption }\end{array}$ & $\begin{array}{l}\text { Municipal water tank- } \\
\text { ers }\end{array}$ & 26,8 \\
\cline { 2 - 3 } & River/spring & 4,0 \\
\hline \multicolumn{2}{|c}{ Total } & \multicolumn{1}{|c|}{ \% Responses } \\
\hline \multirow{2}{*}{ Main reason for water interruption } & \multicolumn{2}{|c|}{} \\
\hline
\end{tabular}


(C) Centre for Cyber Physical Food, Energy \& Water Systems

\begin{tabular}{|l|l|r|}
\hline \multirow{4}{*}{ Total } & Scheduled maintenance & 16,2 \\
\cline { 2 - 3 } & Burst pipe & 4,1 \\
\cline { 2 - 3 } & Daily regular water cuts & 71,4 \\
\cline { 2 - 3 } & Pressure & 2,0 \\
\cline { 2 - 3 } & Do not know & 12,0 \\
\hline & & $\mathbf{1 0 0}$ \\
\hline
\end{tabular}

Household water quality control measures

Only $5 \%$ of surveyed households indicated that they regularly treat water before drinking and $21 \%$ indicated that they occasionally treat water before use. Of total households that treat water before use, $56 \%$ indicated that they use chemicals as the standard water treatment method, while the remaining proportion use heat to boil water before drinking.

\section{Sanitation services}

Just over half (52.4\%) of surveyed households had flushing toilets in their households that were connected to the municipal sewage system. Flush toilet connected to a septic tank accounted for $14.3 \%$ of the total household sanitation service provided to community by the municipality (Figure 19).

Pit latrine with ventilation pipe accounted for $32.3 \%$ of total recorded sanitary services. Over half (52\%) of the participants felt that the rate at which municipality responds to sewage spillage and breaks was slow.

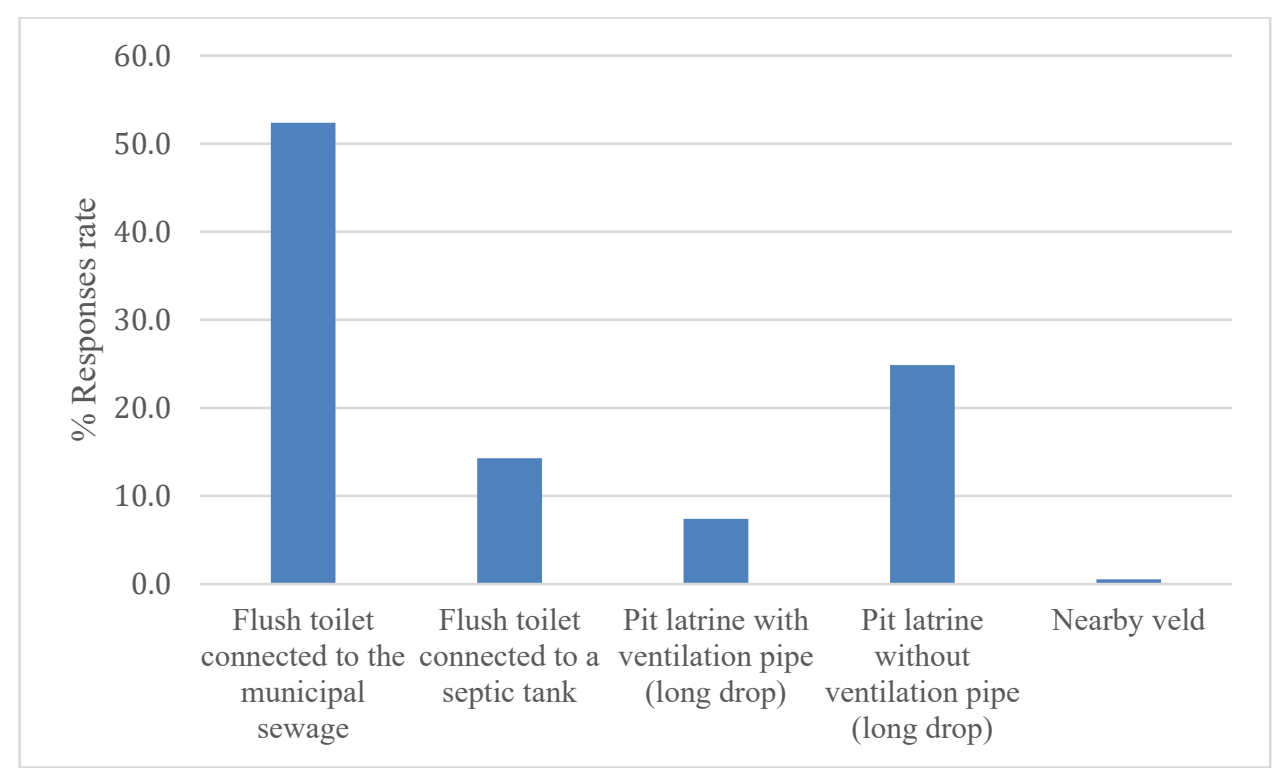


Figure 10: Type of toilet facility used by study participants in Mbombela city

\section{Perspective from stakeholders}

The stakeholders and service providers interviewed during the survey included officials from the Ehlanzeni District Municipality, Mbombela Local Municipality, Provincial Department of agriculture, Inkomati-Usuthu Water Catchment Management Agency and the Provincial office of the National Department of Water and Sanitation.

The National Department of water and sanitation indicated that at the District municipal level (i.e. Ehlanzeni District Municipality), the level of water supply was at $91 \%$. The department thus indicated that it has a backlog of less than $10 \%$. At provincial level the water supply to communities was at $97 \%$ with a backlog of $3 \%$.

Regarding the provision of sanitation services (i.e. toilets) the department indicated that it was almost close to eliminate the bucket toilet system in the province.

The Inkomati-uSuthu Management Agency was worried about the fact that water demand was coming closer to exceeding supply. The major concern was a lack of collaborative planning between the Agency and other role players, which included municipality and government departments. The constant urbanisation was also cited as a cause for concern as new settlements required water.

These views were also shared by the officials of the local municipality, who indicated that promises of houses by politicians were fuelling informal settlement and this was disrupting the implementation of strategies and plans. The consequential effect of this was a huge infrastructure backlog with little management of the infrastructure.

The supply of water infrastructure and its maintenance in informal settlements was lacking. This was despite the municipality having operational and maintenance plans. Resources in the form of funds were constantly being channeled into infrastructure development and management with little allocations to new and emerging settlements.

\section{Discussion}

Service delivery protests linked to water that are prevalent in South Africa [36] indicates the status of water demand and supply in the country. Inland cities like Polokwane and Mbombela are more vulnerable to this as they have little alternative sources and the emerging trend of water scarcity in South Africa is a course for great concern. For cities like Mbombela and Polokwane, smart or digital technologies that can improve the efficient use and management of water are desirable.

In both Polokwane and Mbombela water shortage might escalate as the gap between supply and demand is narrowing. This was obvious in both cities. The gap increases with the total water demand and decreases with water delivered [37]. The main demand for water comes from households that are connected to the municipality reticulation system and used for drinking and sanitation [38]. 
Journal of Digital Food, Energy \& Water Systems, 1 (1): 34-64, 2020

ISSN 2709-4529

(c) Centre for Cyber Physical Food, Energy \& Water Systems

What is clear in both cities are increasing households due to additional settlements, from new formal and informal dwellings. For Mbombela there is additional demand from agricultural sector, especially sugarcane plantations that have low water use efficiency. In general households, agriculture and industrial developments are the major sources of water demand and sanitation services, which both municipalities cannot meet.

As a result, they try to control demand by increasing connection rates [39]. This has a circular impact. As the number of households connected to water supply system increase, this in turn increases the total water demand as well as the gap between demand and supply. With this circular connection, local catchment management agencies as institutions responsible to manage water availability become concerned, especially as there is little consultation among the stakeholders assigned to manages water and ensure its security. It emerged in this survey that stakeholders do not coordinate the planning for water supply and demand. Hence, integrated water resource management emphasizes the necessity for multidisciplinary, multi-sectoral and multi-stakeholder integration in the planning, management and decision making for water management [40].

With current predicament and uncertainty of water security in South African cities, it is obvious that water availability in South Africa has declined due to climate change and usage. The country has an average annual rainfall of almost half of the global average (450 mm compared to a global average of $860 \mathrm{~mm}$ ). To counteract this, cities are sourcing water from areas that fall outside their boundaries. This requires the allocation of extra financial resources and investment in building infrastructure needed to transport and store water sourced elsewhere.

Thus, storage of water in reservoirs has become an integral part of managing water resources in South Africa. Investment in this type of infrastructure requires steady sources of revenue. Unfortunately, this seem to be thwarted by communities are not willing to pay for water services. In ideal situation, the more water delivered to users, the more the potential billable water for municipality.

The overall extension of infrastructure carries the concomitant effect of increasing how fast municipal infrastructure decreases in value and use (i.e. obsolescence rate) [41]. The longer the water supply infrastructure operates above its design capacity, the quicker the infrastructure obsolesces and the quicker it requires refurbishment and replacement [42]. Both cities studied here are likely to experience this

As indicated by Clifford-Holmes et al.[43], the socio-political and institutional context of South Africa's water landscape is varied. This context includes:

$>$ A history of segregation in the form of institutionalized preferences of water supply to certain areas;

$>$ The effects of this segregation are evident in South Africa's high levels of both poverty, inequality and uneven distribution of infrastructure and resources;

$>$ A post-apartheid water management framework that embodies the ambitions of integrated water resource management to rectify mistakes of the past;

$>$ The recognition of the freshwater needs of marine and coastal water bodies e.g. lagoons and estuaries and their subsequent inclusion in the freshwater systems; 
Journal of Digital Food, Energy \& Water Systems, 1 (1): 34-64, 2020

ISSN 2709-4529

(C) Centre for Cyber Physical Food, Energy \& Water Systems

$>$ Developmental planning being enshrined across all the three spheres of government in the country.

Rectifying this has not been a straightforward journey for the South Africa, with many operational manifestations of institutional dysfunction evident and continual challenges in addressing 'who gets what water, when, and how' (Clifford-Holmes et al. 2018[44]). As a norm, effective water resource management requires:

a) Long term accurate assessment of water availability - Planning

b) Short term transition of water in time and space -Operations

c) Reconciliation of demand and supply on a real-time basis without compromising the long-term sustainability of the catchment

d) It is a complex and multi-disciplinary modelling approach and is mainly modelled independently

e) Requires integration

Despite many challenges linked to service delivery and water supply to households, South Africa has committed itself to the ideals of sustainable development goals as a result it is mandatory that the communities be provided with affordable and reliable water and sanitation services. However, with the increasing scarcity of water the supply for water to households, especially in inland cities cannot be guaranteed.

As cities are looking for alternative sources including desalination of marine water, inland water cities do not have this alternative source. These cities need to incorporate water security in their disaster management plans and constantly monitor water availability. Information about water fluctuations and their status of supply can be consistently monitored using digital technologies. Affected cities need to adopt new water technologies to efficiently manage water resources and improve performance. Many innovative technologies are being deployed across the world to monitor water resource usage and leakages.

The importance of supply of water to households has been magnified during Covid19 pandemic, and digital technologies were deployed to monitor water level in the tanks installed where water supply infrastructure is still lacking.

As could be observed in this study, the household water demand in South Africa is increasing. How this can be reduced is the subject for future assessment and analysis. In addition, this study highlighted how water supply and demand are intertwined. This reality presents the complex nature of household water supply and despite. This can potentially be analyzed through systems science and modelling.

\section{$7 \quad$ Acknowledgment}

The study was financially supported by the VW Foundation. Logistics support and the management of funds were provided by the Africa Institute of South Africa, within the Human Sciences Research Council. Participants in the study are greatly acknowledged for their contribution. 


\section{$8 \quad$ References}

[1] Simelane, TS. Systems analysis of the transformation of South African Cities. Unpublished D. Eng Thesis (2017). Durban University of Technology. Durban.

[2] Duffy K, Simelane, TS and Collins, O.C. Income as a primary driver of South African inner-city migration. Theoretical and Empirical Researches in Urban Management (2018). Volume 13, Issue 3 pp 25-36.

[3] MacKellar N, New M, Jack C. Observed and modelled trends in rainfall and temperature for South Africa: 1960-2010. South African Journal of J Science 110 (7/8), 113 (2014).doi.org/10.1590/ sajs.2014/20130353.

[4] DWAF (2004). Water Conservation and Water Demand Management Strategy for the Water Services Sector, Department of Water Affairs and Forestry, Pretoria.

[5] Kashaigili, J.J., Rajabu, K., Masolwa, P. Freshwater management and climate change adaptation: experiences from the Great Ruaha River catchment in Tanzania. Climate and Development 1 (3), (2009) 220-228. http://www.suaire.sua.ac.tz/handle/123456789/1483

[6] Ramos, H. M., McNabola, A., López-Jiménez, P. A., \& Pérez-Sánchez, M. Smart water management towards future water sustainable networks. Water, (2020) 12(1), 58.

[7] Masia, O. A., \& Erasmus, L. D. Smart metering implementation for enabling water conservation and water demand management: An investigation in Gauteng, South Africa. In 2013 Africon (pp. 1-5). IEEE.

[8] Hamilton, S., \& McKenzie, R. Water management and water loss (2014). IWA Publishing

[9] Boujounoui, K., Abidi, A., Bacaoui, A., Amari, K., El. and Yaacoubi, A. The influence of water quality on the flotation performance of complex sulfide ores: case study at Hajar Mine, Morocco. J. South African Inst. Min. Metall. 115, (2015) 124312512015. doi.org/10.17159/2411-9717/2015/v115n12a14

[10] Duong, C, Choung, J, Xu, Z and Szymanski, J. A novel process for recovering clean coal and water from coal tailings. Minerals Engineering 13 (2): (2000) 173-181. doi.org/10.1016/S0892-6875(99)00163-6

[11] Liu, J.M., Sun, Y. Analysis on the characteristics of water resources and measures of sustainable use in the Guanzhong Region. Yellow River 28 (1), (2006) 39- 41. doi.org/10.1007/s10472-010-9211-0

[12] Simonovic, S.P. World water dynamics - global modeling of water resources. Journal of Environmental Management 66, (2002) 249-267. 
Journal of Digital Food, Energy \& Water Systems, 1 (1): 34-64, 2020

ISSN 2709-4529

(C) Centre for Cyber Physical Food, Energy \& Water Systems

[13] Berrueta, L. A., Fernandez, L. A. and Vicente F. Fluorescence study of the solubilization of benzopyrene: application to its detection in coal washing waters. Anal. Chem. Acta 243, (1991) 115-119. doi.org/10.1016/S0003-2670(00)82548-9

[14] Amezaga, J. M., Rotting, T. S., Younger, P. L., Nairn, R. W., Noles, A. J., Oyarzun, R. and Quintanilla, J. A rich vein? Mining and the pursuit of sustainability. Environ. Sci. Technol. 45, (2010) 21-26. doi.org/10.1021/es101430e

[15] Kashaigili, J.J., Rajabu, K., Masolwa, P. Freshwater management and climate change adaptation: experiences from the Great Ruaha River catchment in Tanzania. Climate and Development 1 (3), (2009) 220-228. http://www.suaire.sua.ac.tz/handle/123456789/1483

[16] Ahmad, S., Simonovic, S.P. System dynamics modeling of reservoir operations for flood management. Journal of Computing in Civil Engineering 14 (3), (200)190198. doi.org/10.1061/(ASCE)0887-3801(2000)14:3(190)

[17] Fedorovskiy, A.D., Timchenko, I.Y., Sirenko, I.A. Method of system dynamics in simulating the problems in the comprehensive use of water. Hydrobiological Journal 40 (2), (2004) 87-96. Doi.org/ 10.1615/HydrobJ.v40.i2.100

[18] Qu X., Brame J., Li Q., Alvarez P.J.J., Nanotechnology for a safe and sustainable water supply: Enabling integrated water treatment and reuse. Accounts of Chemical Research 46 (3) (2013) 834 - 843. doi.org/10.1021/ar300029v

[19] Yin J., Deng B., Polymer-matrix nanocomposite membranes for water treatment, J. Membr. Sci. 479 (2015) 256 - 275. doi.org/10.1016/j.memsci.2014.11.019

[20] Shannon M.A., Bohn P.W., Elimelech M., Georgiadis J.G., Marinas B.J., Mayes A.N., Science and technology for water purification in the coming decades. Nature 452 (2008) 301 - 310. doi: 10.1038/nature06599.

[21] Chitnis, N., J. Hyman, and J. Cushing. Determining Important Parameters in the Spread of Malaria Through the Sensitivity Analysis of a Mathematical Model. Bulletin of Mathematical Biology 70: (2008) 1272-1296. doi: 10.1007/s11538-008-9299-0

[22] Naing, L., Winn, T., Rush, B. N. Practical issues in calculating the sample size for prevalence studies. Archives of orofacial sciences 1: (2006) 9-14.

[23] Daniel W.W. Biostatistics: A Foundation for Analysis in the Health Sciences. $7^{\text {th }}$ edition. (1999) New York: John Wiley \& Sons.

[24] Slinger, J. Modelling the physical dynamics of estuaries for management purposes. (1996) University of KwaZulu-Natal, PhD thesis. Pietermaritzburg

[25] Department of Water Affairs and Forestry. Water Conservation and Water Demand Management Strategy for the Water Services Sector, s.1.: (2004) Department of Water Affairs and Forestry, Pretoria. https: www. dwa.gov.za 
Journal of Digital Food, Energy \& Water Systems, 1 (1): 34-64, 2020

ISSN 2709-4529

(C) Centre for Cyber Physical Food, Energy \& Water Systems

[26] Polokwane Municipality, (2010). Polokwane Spatial Development Framework. Polokwane Municipality, Polokwane. Municipalities web page accessed 20 December 2020: https://municipalities.co.za/contacts/1244/city-of-mbombela-local-municipality.

[27] Vegter, J. R. Groundwater Development in South Africa and an Introduction to the Hydrogeology of Groundwater Regions. WRC Report No. TT 134/00, (2000) Water Research Commission, Pretoria, South Africa. http: www.wrc.org.za

[28] Polokwane Water and Sanitation, SBU,(2017), Municipalities web page accessed 20 December 2020: https://municipalities.co.za/contacts/1244/city-of-mbombela-local-municipality.

[29] Polokwane Municipality, (2010). Polokwane Spatial Development Framework. Polokwane Municipality, Polokwane. Municipalities web page accessed 20 December 2020: https://municipalities.co.za/contacts/1244/city-of-mbombela-local-municipality

[30] Polokwane City. Mayoral Report, (2002) Municipalities web page accessed 20 December 2020: https://municipalities.co.za/contacts/1244/city-of-mbombela-localmunicipality.

[31] Statistics South Africa Community survey 2016. www.statsa.gov.za accessed 22 December 2020.

[32] Midgley, D. C., Pitman, W. V. and Middleton, B. J. The Surface Water Resources of South Africa 1990. Volumes 1 to 6. WRC Report Numbers 298/1.1/94 to 298/6.1/94 (text) and 298/1.2/94 to 298/6.2/94 (maps). (1994) Water Research Commission, Pretoria, South Africa

[33] Department of Water and Sanitation's National Water and Sanitation Master Plan 2018 (2018). Department of Water and Sanitation, Republic of South Africa

[34] Statistics South Africa Community survey 2016. www.statsa.gov.za accessed 22 December 2020

[35] Statistics South Africa Community survey 2016. www.statsa.gov.za accessed 22 December 2020

[36] Clifford-Holmes, JK, Slinder, JH, Mbulawa, P and Palmer CG. Modes of failure of South African Local government in the water services sector. Paper presented at the 33rd International Conference of the system dynamics society, 19-23 July 2015, in Cambridge, Massachusetts, USA.

[37] Clifford-Holmes, JK, Slinder, JH, Mbulawa, P and Palmer CG. Modes of failure of South African Local government in the water services sector. Paper presented at the 33rd International Conference of the system dynamics society, 19-23 July 2015, in Cambridge, Massachusetts, USA.

[38] Clifford-Holmes, JK, Slinder, JH, Mbulawa, P and Palmer CG. Modes of failure of South African Local government in the water services sector. Paper presented at the 
Journal of Digital Food, Energy \& Water Systems, 1 (1): 34-64, 2020

ISSN 2709-4529

(C) Centre for Cyber Physical Food, Energy \& Water Systems

33rd International Conference of the system dynamics society, 19-23 July 2015, in Cambridge, Massachusetts, USA.

[39] Clifford-Holmes, JK, Slinder, JH, Mbulawa, P and Palmer CG. Modes of failure of South African Local government in the water services sector. Paper presented at the 33rd International Conference of the system dynamics society, 19-23 July 2015, in Cambridge, Massachusetts, USA.

[40] Clifford-Holmes, JK; Slinger, JH and Plamer, CG. Using System Dynamics Modelling in South African Water Management and Planning. In: Brent, A and Simelane, T (eds). System Dyanimcs Models for Africa's Developmental planning. Africa Insitute of South Africa, Pretoria.

[41] Clifford-Holmes, JK, Slinder, JH, Mbulawa, P and Palmer CG. Modes of fail-ure of South African Local government in the water services sector. Paper presented at the 33rd International Conference of the system dynamics society, 19-23 July 2015, in Cambridge, Massachusetts, USA

[42] Clifford-Holmes, JK, Slinder, JH, Mbulawa, P and Palmer CG. Modes of fail-ure of South African Local government in the water services sector. Paper presented at the 33rd International Conference of the system dynamics society, 19-23 July 2015, in Cambridge, Massachusetts, USA

[43] Clifford-Holmes, JK, Slinder, JH, Mbulawa, P and Palmer CG. Modes of fail-ure of South African Local government in the water services sector. Paper presented at the 33rd International Conference of the system dynamics society, 19-23 July 2015, in Cambridge, Massachusetts, USA

\section{Authors}

Dr. Thokozani Simelane, is the director of research at Africa Institute of South Africa, which is within the Human Sciences Research Council. He is the Senior Research Fellow at SARCHi Chair for innovation studies, Department of Industrial Engineering at the Tshwane University of Technology.

Dr. Claudious Chikozho, is the director of research at African Population and Health Research Centre, Kenya.

Dr. Shingirirai Savious Mutanga is a Research Group Leader, Smart Place, Holistic Climate Change-Climate Services at the Council for Scientific and Industrial Research, South Africa. He is a Senior Research Associate, Department of Operations Management, Faculty of Engineering and Built Environment, University of Johannesburg

Lavhelesani Rodney Managa, is a researcher at Africa Institute of South Africa, which is within the Human Sciences Research Council. He is a $\mathrm{PhD}$ candidate at the University of Pretoria.

Fhulufelo Tshililo, is PhD research intern at the Human Sciences Research Council Dabata, Thandeka is a master's research intern at Africa Institute of South Africa, which is within the Human Sciences Research Council. 